This is a self-archived - parallel published version of this article in the publication archive of the University of Vaasa. It might differ from the original.

\title{
Koronapandemian puhujapositiot sosiaalisen median lapsi- ja perheaiheisissa keskusteluissa
}

\author{
Author(s): Jalonen, Harri; Kokkola, Jussi \\ Title: $\quad$ Koronapandemian puhujapositiot sosiaalisen median lapsi- ja \\ perheaiheisissa keskusteluissa \\ Year: $\quad 2020$ \\ Version: Published version \\ Copyright (C) 2020 Mevi.
}

\section{Please cite the original version:}

Jalonen, H. \& Kokkola, J. (2020). Koronapandemian puhujapositiot sosiaalisen median lapsi- ja perheaiheisissa keskusteluissa. Media \& viestintä 43(4), 303-325. https://doi.org/10.23983/mv.100618 


\title{
Artikkeli
}

\section{Koronapandemian puhujapositiot sosiaalisen median lapsi- ja perheaiheisissa keskusteluissa}

\begin{abstract}
Artikkelissa rakennetaan systemaattinen lähestymistapa sosiaalisen median keskustelujen tutkimukseen. Tarkastelemme artikkelissa puhujaposition käsitteen avulla lapsi- ja perhenäkökulman ilmenemistä korona-aiheisissa sosiaalisen median keskusteluissa maalis-huhtikuussa 2020. Tarkoitamme puhujapositiolla niitä tapoja, joilla keskustelijat rakentavat argumentointiaan, käyttävät retorisia keinoja ja muodostavat puheenvuoroja. Puhujapositiot ovat inmisten itselleen joko tietoisesti tai tiedostamattomasti valitsemia tapoja osallistua keskusteluun. Aineistolähtöisen sisällönanalyysin tuloksena artikkelissa muodostetaan kaikkiaan yhdeksän puhujapositiota: 'riidanhaastaja', 'ilveilijä', 'arvostelija', 'ahdistuja', 'huolestuja', 'laajentaja', 'tietäjä', 'selviytyjä' ja 'auttaja'. Puhujapositiot kuvataan artikkelissa yleisön, median, päätöksentekijöiden ja tiedeyhteisön yhteisvaikutuksesta syntyvinä affektiivisina hybrideinä sosiaalisen median performansseina.
\end{abstract}

AVAINSANAT: Sosiaalinen media, puhujapositio, affektiivinen, performanssi, sisällönanalyysi

W uhanilaiselta märkätorilta loppuvuodesta 2019 leviämään lähtenyt koronavirus muokkasi uusiksi suomalaisten päivittäiset puheenaiheet. Muutos on ollut nopea, kun sitä tarkastellaan sosiaalisen median alustoilla ja netin keskustelufoorumeilla julkaistujen korona-aiheisten viestien esiintymistiheydellä. Joulukuussa 2019 korona-sanan sisältäneitä suomenkielisiä viestejä jaettiin ainoastaan 74 kappaletta. Koronalla tarkoitettiin tuolloin etupäässä Auringon ulompaa kaasukehää tai biljardin kaltaista mailapeliä. Tammikuussa 2020 korona kiinnosti jo yli 20286 viestin verran ja se yhdistettiin selkeästi virusperheeseen, jonka aiempia tunnettuja ihmisestä toiseen tarttuvia taudinmuotoja olivat sars ja mers. Tuore tautimuoto nimettiin covid-19:ksi. Helmikuussa viestien määrä oli noussut jo 83427 viestiin. Maaliskuussa koronasta puhuttiin jo 907754 viestissä. Korona-viestien päivittäinen huippu osui per- 
jantaille 13.3.2020, jolloin viestejä jaettiin liki 55 ooo kappaletta. (Mohawk Analytics 2020.)

Määrän lisäksi epidemian eteneminen näkyi viestien sisällöissä. Vielä tammikuussa korona oli useimmille suomalaisille etäinen ongelma, mikä ilmeni muun muassa huumoria sisältävinä statuspäivityksinä. Monet arvelivat lentokentillä ja turistikohteissa kasvomaskein pukeutuneiden aasialaisten syyllistyvän hätävarjelun liioitteluun. Helmikuussa keskustelujen sävy kuitenkin synkkeni nopeasti. Merkittävänä ilmapiirin muuttumiseen vaikuttavana tekijänä oli helmikuun lopulla Pohjois-Italiasta välitetyt uutiset tautiin menehtyneistä ihmisistä. Kuolonuhrien määrän nopea nousu ja epidemian leviäminen Euroopassa muuttivat uteliaisuuden ja hämmennyksen huoleksi omasta ja läheisten terveydestä. YK:n terveysjärjestö WHO julisti koronan 11.3.2020 pandemiaksi. Viikkoa myöhemmin oli Suomessa hallituksen vuoro julistaa maahan poikkeustila. Viimeistään tällöin kävi selväksi, että taudilla on kansanterveydellisten seurausten lisäksi taloudellisia, sosiaalisia ja poliittisia vaikutuksia. Karanteeninomaisesti eristäytyneiden yli 70-vuotiaiden kansalaisten lisäksi julkisuudessa oltiin huolestuneista koronan vaikutuksista lasten ja perheiden hyvinvointiin. Useissa puheenvuoroissa kannettiin huolta perheistä, joilla oli vaikeuksia jo ennen poikkeustilaa. Koulun yhteiskunnallinen asema sai poikkeusaikana uudenlaisen sisällön, kun iso osa lasten vanhemmista joutui löytämään ratkaisuja etäkoulunkäynnin ja etätyöskentelyn yhteensovittamiseen. (Ks. koronakriisin vaikutuksista lasten hyvinvointiin Erola ym. 2020.)

Tarkastelemme tässä artikkelissa puhujaposition käsitteen avulla lapsi- ja perhenäkökulman ilmenemistä korona-aiheisissa sosiaalisen median keskusteluissa maalis-huhtikuussa 2020. Tarkoitamme puhujapositiolla niitä tapoja, joilla keskustelijat rakentavat argumentointiaan, käyttävät retorisia keinoja ja muodostavat puheenvuoroja (Kokkola ym. 2020, 262).

Etsimme vastauksia seuraaviin tutkimuskysymyksiin:

- Millaisia puhujapositioita sosiaalisen median korona-aiheisissa ja lasten/lapsiperheiden kokemuksista kertovista keskusteluista voidaan tunnistaa?

- Mistä asioista eri puhujapositioissa puhutaan ja millaisia retorisia keinoja viesteissä hyödynnetään?

Artikkeli koostuu johdannon lisäksi neljästä osiosta, joista ensimmäisessä rakennetaan artikkelin teoreettinen viitekehys. Siinä puhujapositiot kuvataan affektiivisina hybrideinä performansseina. Tämän jälkeen esitellään empiirisen aineiston keruu ja toteutetun sisällönanalyysin vaiheet. Neljännessä osiossa analyysin tulokset jäsennetään yhdeksään puhujapositioon. Kustakin puhujapositiosta tarkastellaan keskeisiä puheenaiheita, ilmaisutapoja ja retorisia keinoja. Analyysin yhteydessä esitellään autenttisia esimerkkejä. Johtopäätöksissä arvioidaan artikkelin kontribuutiota sosiaalisen median keskustelujen tutkimukseen ja pohditaan jatkotutkimusaiheita. 


\section{Puhujapositiot sosiaalisen median performansseissa}

Hybridillä tarkoitetaan kahden tai useamman erilaisen asian yhdistelmää. Mediaympäristössä hybridit syntyvät erityisesti teknologisen kehityksen myötävaikutuksella. Viestinnäntutkimuksessa hybridillä viitataan vakiintuneiden mediaorganisaatioiden ja sosiaalisen median yhdistymiseen ja limittymiseen (Chadwick 2013). Hybridisyyden yhtenä ilmenemismuotona on käyttäjälähtöisen sisällöntuotannon nouseminen media-ammattilaisten tuottaman ja joukkotiedotusvälineiden ohjaaman sisällöntuotannon rinnalle - ja monin paikoin myös sen ohi. Portinvartijattomassa sosiaalisessa mediassa kuka tahansa voi olla oman elämänsä päätoimittaja. Kiinnostavimpia sisältöjä tuottavat ihmiset keräävät yleisöjä tavalla, joka aiheuttaa kateutta monissa lehtitaloissa. Toisaalta perinteiset mediaorganisaatiot ovat levittäytyneet sosiaalisen median alustoille ja monista toimittajista on kuoriutunut henkilöbrändejä. Niin sanotulla perinteisellä medialla on edelleen valtansa, sillä usein journalistiset sisällöt ohjaavat, rajaavat ja kehystävät julkisuudessa käytävää keskustelua (Ruoho \& Kuusipalo 2018, 62-63). Mediaympäristön hybridisyyttä voidaan lähestyä tulevaisuudentutkija Alvin Tofflerin (1980) käsitteellä 'prosumerismi', jolloin sillä viitataan sisällöntuottajien ja sisällönkuluttajien roolien sekoittumiseen. On myös ehdotettu englanninkielisten sanojen 'producer' ja 'audience' yhdistämistä, jolloin on luontevaa puhua 'prodiencesta' tai 'praudiencesta' (Villi 2011, 52). Käsitteitä olennaisempaa hybridissä mediaympäristössä on sen oivaltaminen, että sisältö ei ole vain jotakin, joka pakataan tiettyyn muotoon ja toimitetaan tuottajalta kuluttajalle vaan kysymys on dynaamisesta aineistojen ja merkitysten kierrosta (Valaskivi \& Sumiala 2014, 235-236). Lineaarisesti etenevän prosessin sijaan merkityksiä luodaan ja muokataan syklimäisesti. Ylen puoli yhdeksän uutisissa sanottu on sosiaalisessa mediassa ennen säätiedotusta, ja vastaavasti esimerkiksi Donald Trumpin twiittejä analysoidaan perinteisen median ajankohtaisohjelmissa. Usein kysymys on harmittomasta merkitysten muokkaamisesta esimerkiksi sosiaalisen koheesion vahvistamiseksi (esim. Hollenbaugh \& Ferris 2014, 52). Vakavaksi asia muuttuu silloin, kun hybridisyyttä hyödynnetään todellisuuden muokkaamisessa. Tästä varoittavana esimerkkinä Yhdysvaltojen vuoden 2016 presidentinvaalit, joiden yhteydessä sosiaalisessa mediassa kierrätetyillä valeuutisilla ja disinformaatiokampanjoilla vaikutettiin vaalien lopputulokseen (Giglietto ym. 2019, 636-637). Astetta vakavammaksi meno muuttui vuoden 2020 vaaleissa, jolloin sosiaalisessa mediassa kyseenalaistettiin koko vaalien legitimiteetti.

Ideaalitilanteessa sosiaalinen media on inmisten ja ajatusten kohtaamispaikka. Sosiaalisessa mediassa sana on vapaa ja sitä käytetään erimielisyyksien sovittelemiseen ja yhteisten merkitysten muodostamiseen. Käytännön havainnot ja lukuisat tutkimukset kuitenkin osoittavat, että ihmisten ajattelun vinoumien (Kahneman 2011) ja sosiaalisen median palvelujen käyttöä ohjaavien algoritmien (Cheney-Lippold 2017) yhteisvaikutuksesta sosiaalinen media vahvistaa valikoivaa altistumista informaatiolle ja ruokkii mielipiteiden polarisoitumista (Sunstein 2017), mahdollistaa väärän ja harhaanjohtavan tiedon (Vosoughi ym. 2018) sekä poliittisen propagandan levittämisen (Woolley \& Howard 2018). Poliitikkoja ja virkamiehiä syytetään sosiaalisessa 
mediassa armotta. Myös asiantuntijat saavat osansa, kun heidän näkemyksensä eivät vastaakaan kokemustiedon ja maalaisjärjen pohjalta muodostuneita käsityksiä. Seurauksena ei näin olekaan filosofi Jürgen Habermasin (1991) kuvaamia julkisia tiloja, joissa keskustellaan avoimesti ja järkeen vedoten, vaan kommunikaatiotutkija Zizi Papacharissin (2015) kuvailemia affektiivisia julkisia tiloja (affective publics) - virtuaalisesti verkottuneita foorumeja, joissa argumentteja perustellaan asioiden synnyttämillä tunteilla ja mielikuvilla. Raymond Williamsin (1961) tuntemisen rakenteisiin (stuctures of feeling) nojaten Papacharissi $(2015,115-116)$ määrittelee affektiivisen julkisen tilan yhteisölliseksi kokemuksellisuudeksi, jossa ovat samanaikaisesti läsnä sekä ääneen artikuloidut ajatukset että vaiennetut narratiivit. Yhteiskunnallisen ilmiön käsittely affektiivisessa tilassa laajentaa ja vahvistaa ilmiöön kohdistuvaa tietoisuutta, joskaan ei välttämättä riitä tuottamaan syvällistä ymmärrystä. Kyse ei myöskään ole puntaroivaan demokratiakäsitykseen liitetystä kansalaisosallistumisesta. Rationaalisilla argumenteilla on arvoa, mutta ne eivät muodostu affektiivisessa julkisessa tilassa hallitsevaksi argumentointitavaksi (Papacharissi 2015, 116, 120).

Käsitteellistämme koronapandemian merkityksellistämisen affektiiviseksi hybridiksi sosiaalisen median performanssiksi. Merkityksellistämisen affektiivisuudella viittaamme koronapandemian aiheuttamiin sävyltään ja intensiteetiltään vaihteleviin tunnereaktioihin. Tutkimuksissa on havaittu, että sosiaalisen median koronakeskusteluissa tunteet ovat pinnassa (Kaila \& Prasad 2020, 131-133). Epidemian etenemistä seurataan huolestuneena siitä, miten itselle ja läheisille käy. Median välittämien koronavirusta koskevien keskustelujen on todettu lisänneen ihmisten kokemaa stressiä ja mielenterveysongelmia, kuten ahdistusta ja masennusta (Garfin ym. 2020, 355-357; Gao ym. 2020, 3-6). Merkityksellistämisen hybridisyydellä tarkoitamme mediasisältöjen syklimäistä kiertoa perinteisestä mediasta sosiaaliseen mediaan ja päinvastoin (Vaccari ym. 2015, 1056; Sumiala ym. 2016, 100). Koronapandemia tarjoaa otolliset olosuhteet hybridisyydelle, sillä kyse on ihmiskunnan yllättäneestä kriisistä, joille on tyypillistä se, että niiden mediamaisemaan ei ole ehtinyt muodostumaan hallitsevaa tulkintaa. Golebiewskia ja boydia (2018) väljästi mukaillen tulkinnan puuttuminen voidaan määritellä informaatiotyhjiöksi (data void). Muiden tyhjiöiden tapaan myös informaatiotyhjiöillä on taipumusta täyttyä. Sosiaalinen media on sakeanaan melko harmitonta epidemianhallintaan kohdistuvaa spekulointia, mutta tyhjiö on myös houkutellut salaliittoteoreetikkoja ja valeuutisten levittäjiä. Yhtenä esimerkkinä toimii toukokuussa 2020 YouTubessa julkaistu 'Plandemic'-video, jossa tutkijanurallaan sivupolulle ajautunut Judy Mikovits esittää omaperäisiä syytöksiä koronaepidemian syistä ja seurauksista (Alba 2020). Videossa syytöksiä saavat niskaansa niin globaalin talouselämän eliitti kuin tiedeyhteisöissä arvostetut epidemiologitkin. Harhaisesta sisällöstään huolimatta videota katsottiin ensimmäisen viikon aikana yli kahdeksan miljoonaa kertaa. Katsojamääriä olennaisempaa tapauksessa on se intensiteetti, jolla videon ottivat omakseen erityisesti äärioikeistolaista ideologiaa ajavat mediat. Mediaosumia seuraavan Zignal Labsin mukaan Mikovitsin nimi keräsi toukokuun 2020 alkupuolella 14000 päivittäistä osumaa perinteisessä ja sosiaalisessa mediassa (Alba 2020). 
Hybridisyys luo mahdollisuuksia viestinnän performatiivisuudelle. Erving Goffmanin (1959) tekemään jakoon näyttämön ja kulissin välille tukeutuen esitämme, että sosiaalinen media tarjoaa foorumin performatiiviselle käyttäytymiselle. Tarkoitamme performanssilla vuorovaikutusta, jossa luodaan, ylläpidetään, muokataan ja jaetaan menneisyyteen, nykyisyyteen ja tulevaisuuteen kohdistuvia merkityksiä (Jalonen ym. 2020). Kysymys on paljolti tarkoituksellisesta, mutta osittain myös tiedostamattomasta roolin rakentamisesta. Rooleja esitetään erilaisten puhujapositioiden kautta. Virsun (2007, 355-357) ja Ainialan ym. (2020,6) mukaan kielellisten keinojen kautta syntyvät puhujapositiot voivat olla ulkoapäin annettuja tai tietoisesti otettuja. Tässä artikkelissa olemme kiinnostuneita otetuista puhujapositioista. Viittaamme puhujapositioilla niihin puhetapoihin, joiden kautta keskustelijat rakentavat argumentointiaan, käyttävät retorisia keinoja ja muodostavat puheenvuoroja (Kokkola ym. 2020, 262). Jaamme Ainialan ym. (emt., 1) käsityksen siitä, että positiot voidaan tunnistaa tarkastelemalla puheenaiheita ja puheessa hyödynnettyjä kielellisiä valintoja. Sama henkilö voi puhua eri positioista keskustelun aikana tai hyödyntää eri positioiden keino- ja argumentaatiovalikoimaa. Kysymys on roolien ja positioiden päällekkäisyydestä muodostuvasta jatkumosta (Ainiala ym. 2020, 18). Oletuksenamme on, että puhujapositioiden avulla tekstistä voidaan muodostaa tulkinta, joka kertoo puhujan intentioista.

\section{Tutkimuksen toteuttaminen}

Tutkimuksen tutkimusotetta voidaan luonnehtia abduktiiviseksi, sillä sen tavoitteena on tulkinnan systematisointi ja kohdistaminen tutkimuksen johtoajatuksen mukaisesti tärkeiksi oletettuihin seikkoihin. Abduktiivisen päättelyn logiikkaa (Toivonen 1999, 46-47) hyödyntäen tutkimuksen johtoajatus - sosiaalinen media tarjoaa foorumin affektiivisille hybrideille sosiaalisen median performansseille - muodostettiin empiiriseen aineistoon tutustumisen yhteydessä. Puhujapositioiden ohjaamina tutkimuksessa hahmoteltiin tulkinnallinen viitekehys, jonka oikeellisuutta arvioitiin empiirisen aineiston valossa. (Ks. kuvio 1.)

Kuvio 1. Tutkimuksen toteuttaminen.

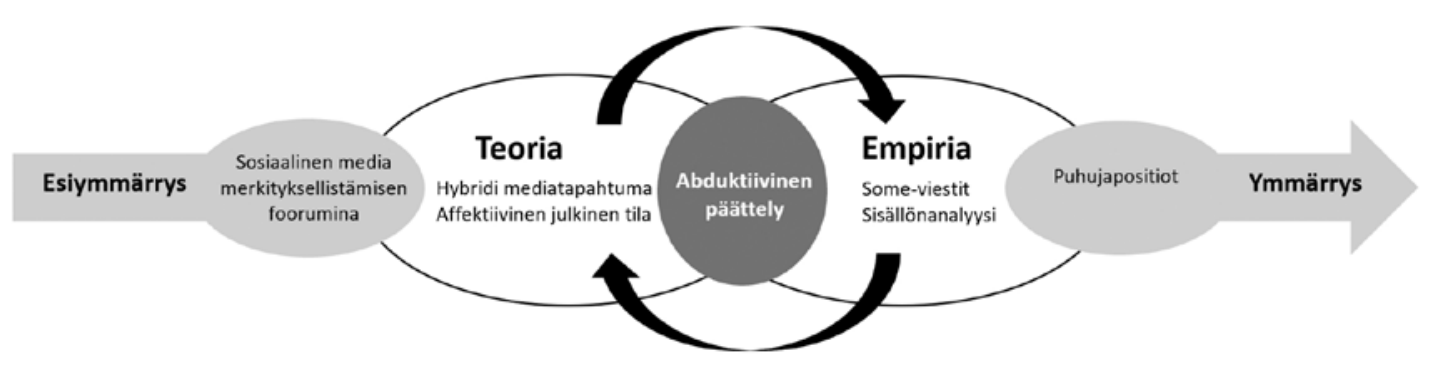


Tutkimuksemme perusaineisto koostuu ajanjaksolla 16.3.2020-30.4.2020 sosiaalisen median alustoilla, internetin keskustelupalstoilla ja mediatalojen uutiskommenttipalstoilla julkaistuista suomenkielisistä viesteistä. Tarkastelujakson ensimmäisenä päivänä Suomi siirtyi poikkeusoloihin, jolloin muun muassa peruskouluissa sekä toisella ja korkea-asteella siirryttiin etäopetukseen. Myös valtaosa valtion ja kuntien kulttuuri- ja liikuntapalvelujen tiloista suljettiin. Samoin lapsille ja perheille suunnattujen julkisten palvelujen saatavuutta rajoitettiin. Tarkastelujakson päättyessä hallitus ilmoitti monien rajoitusten asteittaisesta purkamisesta. Koronatilanne oli koko tarkastelujakson ajan Suomessa epidemiologisesti ja terveydenhuoltojärjestelmän kantokyvyn näkökulmasta hyvin hallinnassa. Kansainvälisesti vertailtuna koronaan sairastuneita ja menehtyneitä oli melko maltillisesti. Terveyden ja hyvinvoinnin laitoksen ylläpitämän tilaston mukaan Suomessa oli 30.4.2020 mennessä todettu 4995 vahvistettua koronavirustapausta ja tautiin oli menehtynyt 211 suomalaista.

Toteutimme aineistohaun Mohawk Analyticsin tietokantaan Boolen logiikkaa hyödyntävällä hakusanayhdistelmällä [korona* OR covid*] AND [lapsi* OR perhe* OR lasten* OR nuori* OR nuorten*]. Haku tuotti yhteensä 149388 osumaa jakautuen eri kanaviin taulukon 1 mukaisesti.

Taulukko 1. Viestien jakautuminen eri kanaviin.

\begin{tabular}{|l|l|}
\hline Kanava & Viestien määrä \\
\hline Keskustelupalsta (suosituimmat www.vauva.fi ja suomi24.fi) & 70286 \\
\hline Twitter & 46437 \\
\hline Facebook & 14672 \\
\hline Blogit & 9495 \\
\hline Uutiskommentti (suosituimmat www.is.fi ja www.kauppalehti.fi) & 6718 \\
\hline Instagram & 1780 \\
\hline Yhteensä & 149388 \\
\hline
\end{tabular}

Viestit analysoitiin sisällönanalyysin periaatteita noudattaen. Toteutimme sisällönanalyysin kolmessa vaiheessa. Analyysin ensimmäinen vaihe koostui aineistoon tutustumisesta. Valitsimme kultakin tarkastelujaksoon kuuluvalta 46 vuorokaudelta satunnaisotannalla 100 viestiä. Viestien hybridimäisen kierron vuoksi sekä satunnaisuuden ja otosvaliditeetin (Krippendoff 2004, 319) varmistamiseksi keräsimme 46 vuorokaudelta eri kellonaikaan julkaistuja viestejä. Luimme näin muodostuvat 4600 viestiä ja teimme muistiinpanot viesteissä esiintyneistä teemoista ja viestien sävystä. Ensimmäisen vaiheen päätteeksi toteutimme teemallisen narratiivianalyysin (vrt. Riessman 2008), jossa tunnistimme kaksi pääkategoriaa (lasten ja lapsiperheiden arki sekä lasten ja lapsiperheiden palvelut) ja kaksi ilmaisun pääsävyä (teemaan myönteisesti tai kielteisesti suhtautuva). Toisessa vaiheessa tunnistimme teemallisen 
narratiivianalyysin pohjalta ja aineistolähtöisten sisällönanalyysin avulla (ks. Tuomi \& Sarajärvi 2004) neljä puhetapaa: 'syyllistäminen', 'alistuminen', 'toteaminen' ja 'eteenpäin katsominen'. Puhetapojen tunnistamisen avulla varmistuimme valitun lähestymistavan sopivuudesta aineistoon. Kolmannessa vaiheessa valitsimme kustakin puhetavasta 100 edustavaksi arvioimaamme viestiä. Otokseksi muodostuneet 400 viestiä analysoimme kiinnittämällä huomiota kolmeen asiaan: i) mistä viestissä puhutaan, ii) miten viestissä puhutaan ja iii) mitä retorisia keinoja viestissä käytetään. Kolmannen vaiheen tuloksena muodostimme kaikkiaan yhdeksän puhujapositiota: 'riidanhaastaja', 'ilveilijä', 'arvostelija', 'ahdistuja', 'huolestuja', 'laajentaja', 'tietäjä', 'selviytyjä' ja 'auttaja'. Kuviossa 2 on havainnollistettu analyysin eteneminen aineistoon sisältyneen www.vauva.fi-sivustolla julkaistun viestin avulla.

Kuvio 2. Aineiston analysointi.

\section{Analyysin 1. vaihe \\ Puheenaihe: lasten kasvattaminen ja arjessa pärjääminen $\rightarrow$ arki \\ Sävy: "ovatko todella niin urpoja" $\rightarrow$ kielteinen \\ Analyysin 2. vaihe \\ Puhetapa: "eivätkö ihmiset tykkää omasta perheestään \\ tai omien lasten kanssa olemisesta?" $\rightarrow$ syyllistäminen}

\section{Analyysin 3. vaihe}

IImaisutavat ja retoriset keinot: kärjistäminen, eettis-moraalinen arviointi, retoriset kysymykset

Puhujapositio: 'arvostelija'
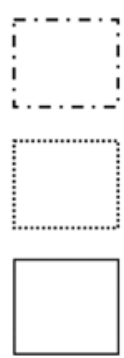

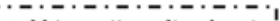
Tämä korona-aika pistää kyllã ihmettelemään monia asioita: - Miksi ihmiset!'hankkivat niin paljon lapsia,;jos eivät jaksa/pysty heitä kasvattamaan?: Eivätkö ihmiset oikeasti tykkää omasta perheestään tai omien lasten kanssa olemisesta? - Ovatko ihmiset todella niin urpoja, etteivät osaa auttaa alakouluikäisiä lapsiaan koulutehtävissä? -Ovatko ihmiset ; todella niin urpoja, ¡etteivät osaa rajata alakouluikäisiä lapsiaan ja/tai kasvattaa heistä edes minimaalisen itsenäisiä? Eriarvoistuminen on lähtöisin kotoa. Ei pelkästään taloudellisista syistä, vaan näiden käsittämättömän kädettömien vanhempien takia.' Itse hoidan etänä työt, ! opiskelut ja lasten etäkoulun tukemisen, jota on vähän, kun lapset tottuneet itsenäisiksi. [...]

Sisällönanalyysiä pidetään subjektiivisena menetelmänä, joka on altis monille vinoumille. Kirjoitettu teksti kantaa aina merkityksiä, joiden tulkintaan ei ole olemassa yleispätevää ohjetta (Krauss 2005, 760). Otosvaliditeetin lisäksi sisällönanalyysissä onkin kiinnitettävä huomiota semanttiseen validiteettiin eli siihen, miten hyvin analyysissä onnistutaan vangitsemaan teksteihin sisältyviä merkityksiä (Krippendoff 2004, 319). Krippendoff (emt.) peräänkuuluttaa sisällönanalyysiltä myös yhteiskunnallista validiteettia. Sisällönanalyysiä tulisi hänen mukaansa tehdä ensisijaisesti teksteille, joilla on laajaa merkitystä. Käsillä olevassa tutkimuksessa semanttista validi- 
teettia on pyritty lisäämään sillä, että keskeiset valinnat ja tulkinnat on tehty kahden tutkijan yhteistyönä. Tutkimuksen yhteiskunnallinen validiteetti nousee itse ilmiöstä, sillä analyysin kohdistaminen koronapandemian käsittelyyn sosiaalisessa mediassa tarjoaa kiinnostavan ikkunan ihmisten arkeen. Näin syntyvää ymmärrystä voidaan hyödyntää esimerkiksi viranomaisviestinnän suunnittelussa.

\section{Yhdeksän puhujapositiota}

Puhujapositiot nähdään artikkelissa ihmisten itselleen joko tietoisesti tai tiedostamattomasti valitsemina tapoina osallistua sosiaalisen median keskusteluihin. Puhujapositiot eivät ole pysyviä vaan ne elävät tilanteen mukaan. Vaikka puhujapositiot heijastelevatkin yksilöiden identiteettejä, ne ovat ensisijaisesti tekstin tasolla tapahtuvaa organisoitumista. Diskurssianalyyttisen sosiaalisen todellisuuden rakentumisen (ks. esim. Pälli 2003, 27-30) sijaan perustamme puhujapositioanalyysimme yleisesti hyväksyttyyn käsitykseen siitä, että retoriikka - yleisön suostuttelu ja vakuuttaminen - on kielenkäytön perustavanlaatuinen ominaisuus (esim. Kennedy 1994, Puro 2005). Sovellamme retoristen keinojen osalta erottelua hyökkääviin ja puolustaviin retorisiin keinoihin (vrt. esim. Jokinen 1999). Hyökkäävässä retoriikassa puhujan tavoitteena on vahingoittaa ja luoda puhumisen kohteesta kielteinen vaikutelma, kun taas puolustavassa retoriikassa kohteesta tai puhujasta luodaan luotettava ja myönteinen vaikutelma. Havainnollistamme puhujapositioiden analyysiä autenttisilla esimerkeillä. Esimerkkien valinnassa on sovellettu Markhamin ja Buchananin (2012) "älä aiheuta pahaa" -periaatetta. Tällä tarkoitamme yhtäältä sitä, että esimerkkien yhteydestä on poistettu tiedot, joiden perusteella puhujat voidaan identifioida ja toisaalta sitä, että esimerkkien valinnassa on kiinnitetty huomiota niiden edustavuuteen suhteessa aineistoon.

\section{Puhujapositio: Riidankylväjä}

Riidankylväjän tavanomainen puheenvuoro kohdistuu viranomaisten ja poliitikkojen toimien moittimiseen. Osa riidankylväjistä näkee ongelmia siinä, että epidemianhallinnassa on asetettu talous terveyden edelle, kun taas toiset ovat sitä mieltä, että terveyttä on korostettu liikaa ja ennen kaikkea talouden kustannuksella. Riidankylväjä hakee konfrontaatiota rinnastamalla poliittisen lähihistorian tapahtumia uuteen tilanteeseen ja spekuloimalla muiden maiden paremmilla käytännöillä. Tyypillistä riidankylväjälle on, että hän arvostelee päätöksentekijöitä vastuunpakoilusta ja kokemattomuudesta. Kun arvostelun kohteena ovat terveydenhuollon ja kasvatusalan ammattilaiset, riidankylväjä näkee ongelmia heidän asiantuntijuudessaan. Riidankylväjä paheksuu yksityisen terveydenhuollon voitontavoittelua ja julkisen terveydenhuollon tehottomuutta. Riidankylväjä ei myöskään epäröi syyttää kanssaihmisiään vastuuttomasta käyttäytymisestä, kuten joukkoliikennevälineissä matkustamisesta nuhaisena ja yskäisenä. Riidankylväjän puhetapa perustuu kyseenalaistamiseen ja vastakkainasetteluun. Reto- 
risesti riidankylväjä hyödyntää tarkoitushakuista ja valikoivaa asioiden esittämistä, asenteellisia sanavalintoja, kielteisiä mielikuvia luovia kielikuvia sekä näkemystensä perustelua näennäisfaktoilla, tarpeettomilla tai keinotekoisilla yksityiskohdilla.

Kaksi esimerkkiviestiä riidankylväjä-puhujapositiosta:

Arvostatko lastentarhanopettajia? Arvostin kovastikin ennen tätä koronaa. Nyt kun joka paikassa lukee miten he ovat " eturintamalla" hoitamassa meidän "ruttoisia" lapsia, joita ne ei edes pitkällä kepillä koskettaisi, niin en kyllä enää arvosta. Eturintamalla olen minä, lääkäri, näen 20-30, kovin sairasta potilasta päivässä hihaton essu suojana. Niille tuodaan terveitä lapsia 2 lasta/ hoitaja ja vielä uskaltavat koko ajan valittaa. (www.vauva.fi)

Ahneissa yksityisissä \#sijaishuoltolaitos'ksissa on alkanut säästäminen sairaslomalla olevien sosionomien kustannuksella: Jos et vie sairaslomasi alkamisesta viikossa lomasi aikana sairaslomatodistusta, jota posti ei tuonut, menetät päivän sairaslomapalkan. \#korona \#lastensuojelu (www.twitter.com)

\section{Puhujapositio: Ilveilijä}

Ilveilijän tyypillinen puheenvuoro kohdistuu koronan mukanaan tuomiin arjen haasteisiin. Ilveilijä haastaa mielellään ja esittää näkökulmia, jotka jäävät hänen mielestään yleisessä keskustelussa liian vähälle huomiolle. Ilveilijä saattaa esimerkiksi muistuttaa siitä, että kaikilla ei ole työtä, jota voi tehdä etänä. Osa ilveilijöiden puheenvuoroista on melko harmittomia, kuten ne, joissa arvellaan, että nykyihmiset ovat tottuneita liian helppoon elämään eivätkä siksi kykene toimimaan kriisiolosuhteissa. Ilveilijät eivät ole salaliittoteoreetikkoja, vaikka monet heistä pyrkivätkin herättämään epäilyjä asioiden todellisista taustoista ja yhteyksistä. Epäilijöiden mukaan esimerkiksi sosiaali- ja terveydenhuollon toimijat puolustavat koronakriisissäkin etupäässä saavutettuja etuja. Osaa ilveilijöistä näyttäisi motivoivan kanssaihmisten provosointi. Ilveilijä voi toivoa koronan tarttumista vastuuttomasti käyttäytyviin kanssaihmisiin ja joskus hän yhdistää koronan yhteiskunnallisesti arkaluontoisiin teemoihin, kuten maahanmuuttovastaiseen keskusteluun. Ilveilijän puhetapa perustuu taktiseen uhriutumiseen ja kanssaihmisten sanomisten hyödyntämiseen oman asiansa edistämisessä. Ilveilijälle on tyypillistä kanssaihmisten kokemusten vähättely. Omien kokemustensa käsittelyssä ilveilijä hyödyntää ironiaa. Retorisesti ilveilijä luottaa asioiden rinnastamiseen ja epämääräistävään kielenkäyttöön. Ilveilijä vihjailee, leikittelee ja hyödyntää kiertoilmaisua. Lähteitä hän käyttää valikoivasti ja tarkoitushakuisesti.

Kaksi esimerkkiviestiä ilveilijä-puhujapositiosta:

Okei. Monen kohdalla on varmaan tilanne, että kun lapset on kotona, mahdollisesti etäopetuksessa ja vanhemman pitäisi tehdä etätöitä, aikaa somettamiseen ei jää kuten ennen. (www.vauva.fi) 
Huolestuttavaa on, että samaan aikaan lastensuojeluilmoitusten määrä on vähentynyt. Kun koulut ovat etäopetuksessa, koulun tekemien lastensuojeluilmoitukset ovat laskeneet. Kun huomioidaan, että kynnys tehtailla lastensuojeluilmoituksia jokaisesta pikkuasiasta on Suomessa jatkuvasti laskenut paranoidiselle tasolle, tässä ei taida olla mitään kovin huolestuttavaa. Ongelma onkin nyt siinä, jos yliviritettyä ilmoituskynnystä ennestään yliviritetään. Tällaisessa tilanteessa mielikuvitus laukkaa ja pienetkin ongelmat raportoidaan vakavina. On selvää, että jokainen haluaa pitää nyt työpaikkansa. Lastensuojelu ja siihen liittyvä liiketoiminta on siitä onnellisessa asemassa, että se itse täysin määrittää tarpeensa, jolloin työt ovat ikuisesti turvattuja. Jos työpaikat ovat uhattuina, se vain tarkoittaa suurta uhkaa yhteiskunnassa, jolloin resursseja tarvitaan lisää. Taitaa olla viimeinen ala Suomessa uhattuna. (www.uusisuomi.f)

\section{Puhujapositio: Arvostelija}

Arvostelijan tehtävänä on ristiriitojen ja epäjohdonmukaisuuksien osoittaminen poliitikkojen ja asiantuntijoiden sanomisten ja tekemisten välillä. Kun kohteena ovat vanhemmat, arvostelijan syytöksissä toistuvat ilmaisut itsekkyydestä, uusavuttomuudesta ja välinpitämättömyydestä. Arvostelija ei arkaile myöskään moralisointia, kun näkee sellaiseen aihetta. Hän saattaa esimerkiksi epäillä, että koronaa käytetään tekosyynä huonolle käyttäytymiselle. Osansa arvostelusta saavat myös sosiaali- ja terveys-, opetus- ja varhaiskasvatusalan ammattilaiset. Arvostelija on vakuuttunut, että julkinen palvelujärjestelmä ei ole tehtäviensä tasalla. Todistusaineistona tästä arvostelija pitää sitä, että korona vuoksi on vaikea saada muita tarpeellisia palveluja. Arvostelijan puhetapa perustuu kanssaihmisten moraalis-eettiseen arviointiin. Arvostelija kärjistää ja vähättelee muiden toimintaa. Arvostelija luottaa kyseenalaistamiseen ja hyödyntää retorisia kysymyksiä. Kun arvostelija viittaa auktoriteettiin, hän tekee sen valikoivasti.

Kaksi esimerkkiviestiä arvostelija-puhujapositiosta:

Olemme perhekuntoutuksessa omassa kodissamme, ja kuntoutukseen liittyy työntekijöiden käynnit meillä joka päivä. Ongelmaksi on muodostunut kotikoulu ja suurentunut tartuntariski näiden työntekijöiden käydessä meillä ja muissa perheissä. Tarvitsisin ajoittain apua tuohon kotikouluun mutta sosiaalityöntekijän kanta on että ellen saa sitä sujumaan niin lapsi voisi mennä kouluun. Eli tämä kuntoutusprojekti ajaa koronan ohitse. Minua tämä asetelma tympii, koska oikeaa apua ei näemmä saa. (www.suomi24.fi)

Aamulla voi tulla viesti, että pitää tehdä mokkapaloja. Missä perheessä on niiden ainekset joka hetki saatavilla? Jos tekemisessä ei onnistuta, on sitten "huoli lapsen selviämisestä". Eikö \#koulu;n pitäisi tukea lapsia? \#Korona \#COVID19FI \#lastensuojelu (www.twitter.com) 


\section{Puhujapositio: Ahdistuja}

Ahdistuja on huolissaan koronan vaikutuksista omaan ja lähipiirinsä elämään. Ahdistuja kokee jatkuvan yhdessäolon tekevän parisuhteesta raskaan. Tilannetta ei helpota omien etätöiden ja lasten etäkoulun yhteensovittaminen. Ahdistujat ovat huolissaan henkisestä jaksamisestaan sekä taloudellisesta selviämisestään. Ahdistujat kertovat myös yksinäisyydestä ja lastenhoito-ongelmista sekä jakavat tuntemuksiaan ongelmista, joita seuraa siitä, että monet julkiset palvelut ovat koronan vuoksi huonosti saavutettavissa. Ahdistujan puhetavassa korostuvat itsesääli ja oman tilanteen voivottelu. Ahdistuja saattaa liioitella ongelmia ja kuvitella pahimman mahdollisen lopputuloksen. Tyypillistä on lisäksi se, että ahdistujat korostavat oman tai läheistensä elämäntilanteen erikoislaatuisuutta. Retorisesti ahdistuja vetoaa kielteisiin tunteisiin ja omiin huonoihin kokemuksiin. Ahdistujan sanavalinnat ovat melko tarkoitushakuisia ja asenteellisia.

Kaksi esimerkkiviestiä ahdistuja-puhujapositiosta:

Olen hoitovapaalla pienen lapsen kanssa ja oma jaksaminen alkaa olla loppu. Lapsi on kitisevä ja vaativa, ei suostu nukkumaan enää ollenkaan päiväunia, joten mitään edes 5 min lepohetkeä en saa. [...] Meidän ns. tukiverkot ei jaksa olla lapsen kanssa, sanovat että eivät pärjää tai muuten on kiireitä, esim. isovanhemmat siis, jotka kaikki neljä ovat eläkkeellä ja asuvat melko lähellä. [...] Täällä meidän kunnassa vaan on ajettu koronan takia alas neuvolatoiminta ja vastaava, puhelinaikoja sinne saa mutta ei muuta. (www.vauva.fi)

Miten selviätte? Miten jaksatte ihmistä joka ei välitä teistä eikä itsestään? Eikä ole paikkaa mihin mennä eikä ketään jota nähdä. Ei pysy pää kasassa. Musta tuntuu etten selviä. OIlaan varmaan molemmat masentuneita ja tämä paska eristys päällä lisää ahdistusta. Oma terveys on reistaillut ja olen pysynyt kotona. Mies ei välitä tippaakaan. [...] Musta tuntuu että olen aivan mitätön, surkea paska ja arvoton. Ei ole jäljellä mitään siitä itsetunnosta mitä oli eikä suhteesta. Epämiellyttävää ja ankeaa. Mies huutaa ja kiroaa joka päivä. (www.vauva.fi)

\section{Puhujapositio: Huolestuja}

Huolestujan tyypillinen puheenvuoro kohdistuu lasten tulevaisuuteen ja erityistä tukea tarvitsevien lasten selviytymiseen. Huolestuja muistuttaa mielellään, että monella lapsella on jo valmiiksi huonot kotiolot ja että poikkeusolot kohtelevat lapsia epätasaarvoisesti. Osaa huolestujista arveluttaa taloudellisten ongelmien kärjistyminen, jos poikkeusolot pitkittyvät. Lisäksi monet heistä ovat huolissaan lapsi- ja perhepalvelujen saatavuudesta ja palvelujen tuottamisessa tarvittavien resurssien riittävyydestä sekä poikkeusaikana että sen jälkeen. Huolestujan puhetavassa korostuu vastuu heikossa asemassa olevien ihmisten tilanteesta. Huolestuja saattaa kritisoida asioiden hoitamista, mutta välttää kuitenkin tarpeetonta kärjistämistä. Huolestuja rakentaa puheen- 
vuoronsa ilmiön yleisyyden, ei omien kokemustensa varaan. Retorisesti huolestuja luottaa neutraaliin ilmaisuun ja viittaa mielellään auktoriteetteihin.

Kaksi esimerkkiviestiä huolestuja-puhujapositiosta:

Poliisien kotihälytykset ovat tuplaantuneet nyt korona-aikana. Lasten huostaanottojakin on tehty normaalia enemmän. Se kertonee kuinka ihanaa ja auvoista perhe-elämä on. Mä uskon että jos tilanne on jo valmiiksi ollut huono niin nyt se on kiristynyt entisestään. Yleensä jos huostaanottoon päädytään niin perhe on ollut lastensuojelun asiakas jo ihan hyvän tovin. (www.is.fi)

Etätöiden ja etäkoulun aloittaminen, muuttunut taloudellinen tilanne, henkinen kuorma, pelko, normaalien tukirakenteiden katoaminen ja esimerkiksi tuttujen palautumismahdollisuuksien katoaminen on kaikkea muuta kuin pelkästään sohvalla istumista. On todella inhimillistä kuormittua jo yhdestä muutoksesta, saati siitä kun koko arki menee uusiksi. On todella inhimillistä tarvita aikaa sopeutumiseen kaiken uuden keskellä. On todella inhimillistä väsyä lapsiin ja puolisoon ja keskittyä vain omaan selviytymiseensä. On todella inhimillistä olla jaksamatta mitään ylimääräistä. Vaikka minä valmennan ihmisiä elämäntapamuutoksissa, muistutan aina, että on aikoja jolloin ei ole järkevää tehdä isoa muutosta. Joskus resurssit menevät vain selviämiseen ja joskus tärkein asia on hengittäminen. \#koronavirus \#coronavirus \#mielenterveys \#mieli \#kehokertoo \#maanantai \#kuormittuminen \#kuormitus \#väsymys (www.instagram.com)

\section{Puhujapositio: Laajentaja}

Laajentaja pyrkii puheenvuoroillaan asettamaan koronapandemian historialliseen kontekstiin. Hänen mukaansa koronakriisi on todellinen, mutta samalla laajentaja muistuttaa muita, että kriiseistä on aiemminkin selviydytty. Laajentaja rohkaisee ajattelemaan ja tavoittelemaan myös epätavanomaisia ratkaisuja. Laajentaja on jossain määrin huolissaan palvelujärjestelmän kestokyvystä ja resursseista, mutta arvelee samalla, että korona osoittaa rakenteista puutteita ja prosesseista valuvikoja tavalla, jota voidaan hyödyntää järjestelmän kehittämisessä. Laajentajan puhetapa rakentuu asioiden yhdistelemiselle ja vertailemiselle. Laajentaja osaa vaatia, mutta ehdottaa myös itse ratkaisuja. Retorisesti laajentaja luottaa tapahtumien epäsuoraan kuvaamiseen sekä ilmiön yleisyyteen ja aiempiin tapahtumiin viittaamiseen.

Kaksi esimerkkiviestiä laajentaja-puhujapositiosta:

Koronakriisi korostaa riittävän sosiaaliturvan merkitystä. Lapsena koetun köyhyyden vaikutukset ovat merkittäviä. Tästä on näyttöä 1990-luvun laman ajalta. Laman seurauksena tehdyt leikkaukset pahensivat entisestään lasten ja perheiden tilannetta. Koronakriisissä Suomella ei ole varaa toistaa 199o-Iuvun laman kaltaisia leikkauksia. Vaikka leikkauksista 
pidättäytyminen maksaa lyhyellä aikavälillä, vielä kalliimmaksi tulee lisääntyvä syrjäytyminen ja yhteiskunnan ulkopuolelle jääminen. Kriisiaikanakin on syytä muistaa, että hyvinvoinnin perusta rakentuu lapsuudessa. (www.facebook.com)

Koronaepidemian myötä perheet viettävät tiiviisti aikaa omissa kodeissaan. Poikkeusolot koettelevat perheitä ja huoli haavoittuvassa asemassa olevien lasten tilanteesta on kasvanut. Erilaisia sähköisiä palveluita kehitetään paljon, haasteena on kuitenkin palveluiden hajanaisuus. Miten perheet löytävät palvelut, jos perheiden kanssa työskentelevät ammattilaisetkaan eivät tiedä mitä kaikkea perheille on verkossa tarjolla? Nyt jos koskaan tarvitaan sähköistä perhekeskusta. (www.facebook.com)

\section{Puhujapositio: Tietäjä}

Tietäjän tyypillinen puheenvuoro sisältää viittauksia viranomaisten määräyksiin ja asiantuntijoiden ohjeistuksiin. Tietäjä raportoi säännönmukaisesti epidemian etenemisestä kertovia kotimaisia ja kansainvälisiä tilastoja. Hän myös jakaa mielellään koronaan liittyvää tutkimustietoa sekä uutisia ja selvityksiä palvelujärjestelmän toimivuudesta ja toimimattomuudesta. Tietäjä suhtautuu koronapandemiaan viileän asiallisesti ja hänen puheensa on korostuneen faktapohjaista. Tarvittaessa tietäjä myös toimii selkeästi virheellisen tiedon oikaisijana ja väärinkäsitysten korjaajana. Tietäjän puhetapa rakentuu pyrkimykselle esiintyä puolueettomana asioiden kuvaajana ja luotettavan tiedon levittäjänä. Retorisesti tietäjä hyödyntää tapahtumien suoraa kuvausta ja luottaa auktoriteetteihin viittaamiseen.

Kaksi esimerkkiviestiä tietäjä-puhujapositiosta:

Karanteenit ja kotiin eristäytyminen lisäävät sukupuolittuneen perheväkivallan uhkaa. Tuore paperi tarkastelee pandemioiden vaikutusta naisiin ja lapsiin kohdistuvana väkivaltaan: /https://cgdev.org/publication/pandemics-and-violence-against-women-andchildren\#korona" (www.twitter.com)

Sijoitettujen lasten ja vanhempien tapaamiset poikkeusoloissa ovat puhututtaneet. Eduskunnan oikeusasiamiehen ratkaisu huostaanotettujen lasten yhteydenpidon toteuttamisesta koronapandemian aikana luettavissa EOA:n sivuilla. \#sijaishuolto \#lastensuojelu \#oikeusasiamies \#koronafi (www.twitter.com)

\section{Puhujapositio: Selviytyjä}

Selviytyjän tyypillinen puheenvuoro kohdistuu jokapäiväisiin asioihin. Selviytyjä korostaa arjen iloja ja pyrkii kääntämään arkeen kuuluvia harmeja pieniksi voitoiksi. Esimerkiksi poikkeusolojen hyvänä puolena hän näkee sen, että vanhemmilla jää 
enemmän aikaa lapsille. Hän jakaa mielellään omakohtaisia ja läheistensä selviytymistarinoita. Selviytyjä näkee mahdollisuuksia siellä, missä toiset näkevät ongelmia. Selviytyjä ei myöskään unohda kiittää, kun näkee sellaiseen aihetta. Tällöin kysymys on usein auttajalleen melko pienistä, mutta autettavalle merkityksellistä asioista, kuten esimerkiksi kaupassa käymisestä tai lastenhoitoavusta. Selviytyjä arvelee, että koronakriisistä voi seurata myös myönteistä kehitystä, kuten uudenlaista solidaarisuutta ja toisista välittämisen kulttuuria. Hänen mukaansa koronakriisi on saattanut laittaa myös arvoja hyvällä tavalla uuteen järjestykseen. Selviytyjä arvostaa viranomaisten ja asiantuntijoiden toimintaa. Hän jakaa sosiaali- ja terveys-, opetus- ja varhaiskasvatusalan ammattilaisten toiminnasta kertovia selviytymistarinoita. Selviytyjän puhetapa rakentuu hyvien asioiden esilläpidolle. Vaikeuksiin hän suhtautuu oppimiskokemuksina. Retorisesti selviytyjä luottaa myönteisten tunteiden ja tarinoiden voimaan, omiin kokemuksiin viittaamiseen sekä yhteisten arvojen korostamiseen.

\section{Kaksi esimerkkiviestiä selviytyjä-puhujapositiosta:}

Olen 2.Ik ope ja häkellyttävän hyvin olen saanut etäopetuksen käyntiin. Tänään pidin kaksi oppituokiota etänä, toisella käytiin läpi suomen kielen asioita ja toisella matematiikkaa, mm. tehtiin päässälaskut opiskeltavasta asiasta. Mukana oli 15/21 oppilasta. Loppuihin olin yhteydessä erikseen. Silti uskon, että 2/3 luokasta tulee maanantaina paikalle. Ihan vaan sen takia, että on kiva nähdä kavereita ja päästä taas kouluun. Koronan leviäminen on nyt varmistettu. Tulen ma kertomaan, osuinko oikeaan. (www.vauva.fi)

Meille ei mitään erikoista koronalta ollaan piilossa, kun ollaan riskiryhmään kuuluvia. Pojan syntymästä tulee to jo 1V1kk kehitysikä LA ajann ikä tässä kuussa 10kk. $1 \mathrm{~V}$ neuvolassa $50 \mathrm{~g}$ vajaa $10 \mathrm{~kg}$ ja $74,5 \mathrm{~cm}$ pitkä siis $1 \mathrm{kk}$ sitten. Konttaa, ryömii, istuu ja nousee seisomaan syö itse tuttipullosta. Edelleen kierto kateissa itsellä :sadoo1 10-150kp. Mies lähtee armeijaan heinäkuussa ja ehkä sen $1 v$ on max poissa mietitään sitten hoitoihin palaamista, kun pari kuukautta vajaa $3 \mathrm{v}$ poikakin on ja olen palannut viimeistelemään opintoihini. (www.vau.fi)

\section{Puhujapositio: Auttaja}

Auttajan tyypillinen puheenvuoro rakentuu ratkaisukeskeisyydelle. Auttaja jakaa vertaistukena esimerkiksi etäopetusvinkkejä, neuvoja uutisvirran tulkintaan sekä turvalliseen kaupassakäyntiin ja ulkoiluun. Auttaja muistuttaa heikossa asemassa, kuten lastensuojelun kohteena olevien oikeuksista. Hänen mukaansa poikkeusoloissakin yhteiskunnan on pidettävä huolta heikoimmistaan ja tarjottava matalankynnyksen palveluja. Auttaja ohjaa apua tarvitsevia kanssaihmisiään mielellään kansalaisjärjestöjen, kuntien ja seurakuntien sekä yritysten palvelujen äärellä. Auttajan puhetapa perustuu myötäelämiselle, lohduttamiselle ja kannustamiselle. Retorisesti auttaja 
vetoaa yhteiseen arvopohjaan, jakamattomiin ihmisoikeuksiin ja asiantuntijoiden tarjoamaan tutkittuun tietoon. Auttaja luottaa myönteisiä mielikuvia luoviin kielikuviin.

Kaksi esimerkkiviestiä auttaja-puhujapositiosta:

MLL:n paikalliset kerhot ja tapahtumat ovat koronaviruksen aiheuttaman poikkeustilan aikana tauolla, mutta tukea ja toimintaa on tarjolla siitä huolimatta paljon. Puhu koronaviruksesta lapsen ja nuoren kanssa - ohjeet koronaviruksesta puhumiseen ja poikkeustilanteen käsittelyyn lapsen kanssa. Artikkeli on käännetty kymmenelle eri kielelle. (www.facebook.com)

Lastensuojelun Keskusliiton sivuilta löytyy monia hyviä oppaita ja vinkkipaketteja poikkeusoloihin. Tässä hyvä "huoltajan selviytymisopas koronaviruskaranteeniin ja kotiopetukseen". Kannattaa tutustua! (www.facebook.com)

Aineistosta tunnistetut puhujapositiot voidaan sijoittaa toisiinsa nähden järjestykseen itsekeskeisyyden, ratkaisukeskeisyyden, hyväntahtoisuuden ja hallinnantunteen perusteella (kuvio 3). Itsekeskeisyys tarkoittaa suoriutumisen korostamista, joka näkyy henkilökohtaisen menestymisen osoittamisena ja toisten tekemisten väheksymisenä. Ratkaisukeskeisyys ilmenee erilaisten selviytymiskeinojen aktiivisena etsimisenä, kun taas hyväntahtoisuus konkretisoituu myötäelämisenä ja vertaistukena kanssaihmisten kokemuksille. Hallinnantunne syntyy yksilöiden käsityksistä koskien heidän kykyään vaikuttaa kanssaihmisiin sekä yksilöiden käsityksistä kanssaihmisten riippuvuudesta suhteessa itseensä (Anderson ym. 2012, 314).

Kuvio 3. Yhdeksän puhujapositiota itsekeskeisyyden, ratkaisukeskeisyyden, hyväntahtoisuuden ja hallinnantunteen ulottuvuuksilla.

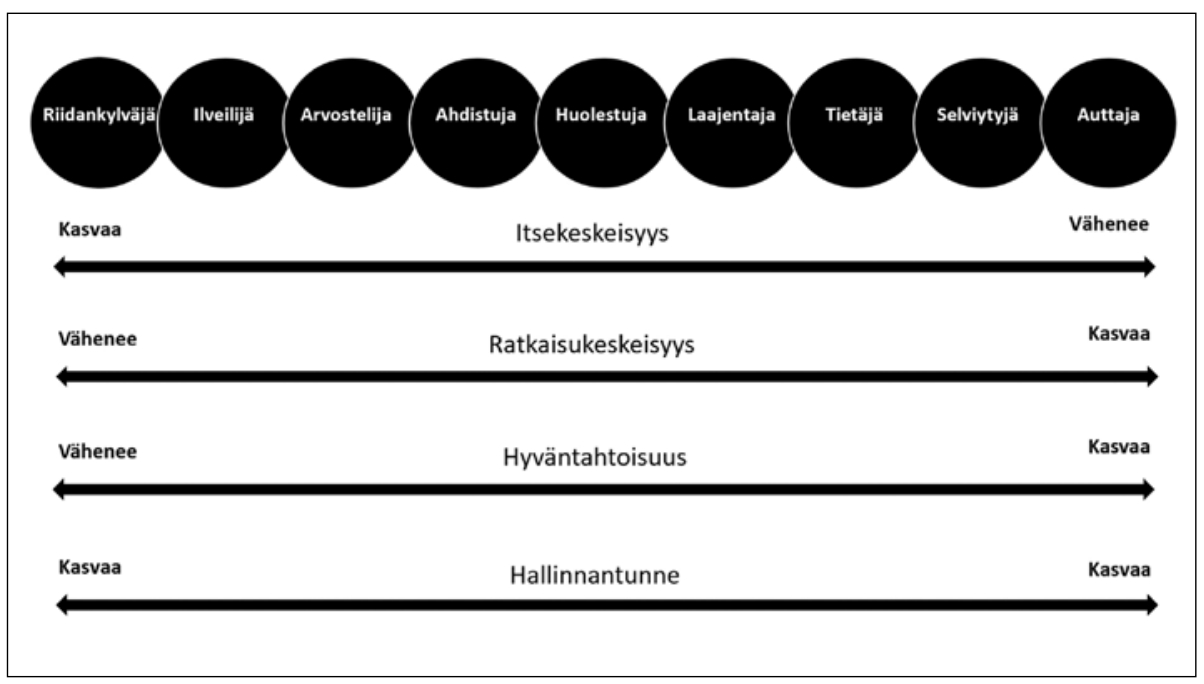


Riidankylväjille ja ilveilijöille on tyypillistä itsekeskeisyydestä ammentava argumentointi. Heille toisten kokemukset ovat raaka-ainetta, jota voi muokata erilaisiin tarpeisiin. Riidankylväjiä ja ilveilijöitä ei voida luonnehtia hyväntahtoisiksi, sillä he eivät etsi ratkaisuja vaan syntipukkeja. Syntipukkien etsiminen on samalla heille keino hallinnantunteen rakentamiseen, ja siksi voidaankin sanoa, että syntipukkien löytäminen antaa heille kokemuksen siitä, että he kykenevät vaikuttamaan keskusteluihin. Riidankylväjät ja ilveilijät eivät myöskään vierasta valeuutisten ja disinformaation hyödyntämistä. Riidankylväjän puhetapa on ilveilijää suoraviivaisempi ja konfliktinhakuisempi. Ilveilijä nauttii asioiden hämmentämisestä, kun taas riidankylväjä pyrkii synnyttämään yhteenottoja. Arvostelija on piirun verran riidankylväjää ja ilveilijää ratkaisukeskeisempi, sillä arvostelija saattaa esittää esiin nostamiinsa ongelmiin myös ratkaisuja. Yleensä arvostelijan ratkaisuehdotuksia ohjaa kuitenkin vakaa usko omiin kykyihin ja siksi arvostelijan puhetapaa voidaan luonnehtia melko itsekeskeiseksi. Pyrkimys välttää selkeästi virheellisten tai puutteellisten tietojen hyödyntämistä vähentää samalla arvostelijan kokemaa hallinnantunnetta. Ahdistujalle on leimallista poikkeuksellisen vahvat kielteiset näkemykset omaan ja läheistensä tulevaisuuteen. Ahdistuja ei lähtökohtaisesti kerro pahasta olostaan muiden kiusaksi vaan se on hänelle eräänlainen itseterapoinnin muoto. Myös huolestuja näkee tulevaisuuden synkkänä, mutta ahdistujaan verrattuna huolestuja kykenee käsittelemään huolestumistaan ratkaisukeskeisemmin. Itsekeskeisyyden ulottuvuudella huolestuja on ahdistujaa yhteisöllisempi, mikä näkyy erityisesti siinä, että huolestuja katsoo tulevaisuuteen myös omaa välitöntä lähipiiriään laajemmin. Laajentaja on kiinnostunut koronapandemian seurauksista. Laajentaja rakentaa hallinnantunnetta tunnistamalla ja vaatimalla ratkaisuja. Tietäjän puhetapa on korostuneen neutraali ja objektiivinen. Tietäjä esittää itsensä valistajaksi, jonka tehtävänä on informoida pandemian syistä, etenemisestä ja seurauksista. Selviytyjä viestii ratkaisukeskeisesti ja hyväntahtoisesti. Selviytyjä ei epäröi kiittää, kun tunnistaa sellaiselle syyn. Selviytyjä viestii hallinnantunnettaan jakamalla omakohtaisia kokemuksia, joiden kaarena usein "vaikeuksien kautta voittoon". Auttajalla on kykyä asettua toisten asemaan. Auttaja ei tyydy tietäjän tapaan informoimaan tutkimuksista ja hyvistä käytännöistä, vaan hän pyrkii löytämään keinoista toimivimmat.

Koronapandemia on korostuneen monimediainen tapahtuma (vrt. Sonnevend 2016), joka on tarjonnut erilaisia osallistumisen mahdollisuuksia ja houkutellut erilaisiin kerronnantapoihin. Pandemian syitä, etenemistä ja seurauksia on merkityksellistetty loputtoman tuntuisesti sekä perinteisessä että sosiaalisessa mediassa. THL:n asiantuntijoista ja STM:n virkamiehistä on tullut julkisuuden henkilöitä, joiden sanomisia ruoditaan lehtien palstoilla ja internetin keskustelufoorumeilla. Poliitikkoja on keväällä 2020 arvioitu lähinnä sen perusteella, mikä on heidän näkemyksensä taudin etenemisen hidastamiseen. Asiantuntijoiden semanttiset valinnat ovat synnyttäneet väittelyjä. Useimpien lähipiiristä löytyy itseoppineita virologeja, jotka osaavat selittää, mitä tarkoitetaan "käyrän loiventamisella" ja miksi se on tärkeää. Talouden näkökulmasta pandemiaa katsoneet ovat nähneet edessä synkempiä aikoja kuin 9o-luvun alun lamavuodet. Sosiaalisen median alustoilla korona oli maalis-huhtikuussa 2020 selke- 
ästi suosituin puheenaihe. Se jätti päivittäin varjoonsa muun muassa huolen ilmastonmuutoksesta ja presidentti Donald Trumpin tahdittomuudet. Esimerkiksi ruotsalainen ilmastoaktivisti Greta Thunberg mainittiin maalis-huhtikuussa 2020 suomenkielisissä sosiaalisen median viesteissä vain 334 kertaa.

\section{Keskustelu ja johtopäätökset}

Tunteet, mielikuvat ja subjektiiviset kokemukset ovat affektiivisen hybridin mediaperformanssin polttoainetta, mutta performanssissa luodut merkityksenannot eivät jää sosiaaliseen mediaan vaan heijastuvat monin eri tavoin yhteiskunnallisten instituutioiden toimintaan (kuvio 4).

Kuvio 4. Affektiivinen hybridi sosiaalisen median performanssi.

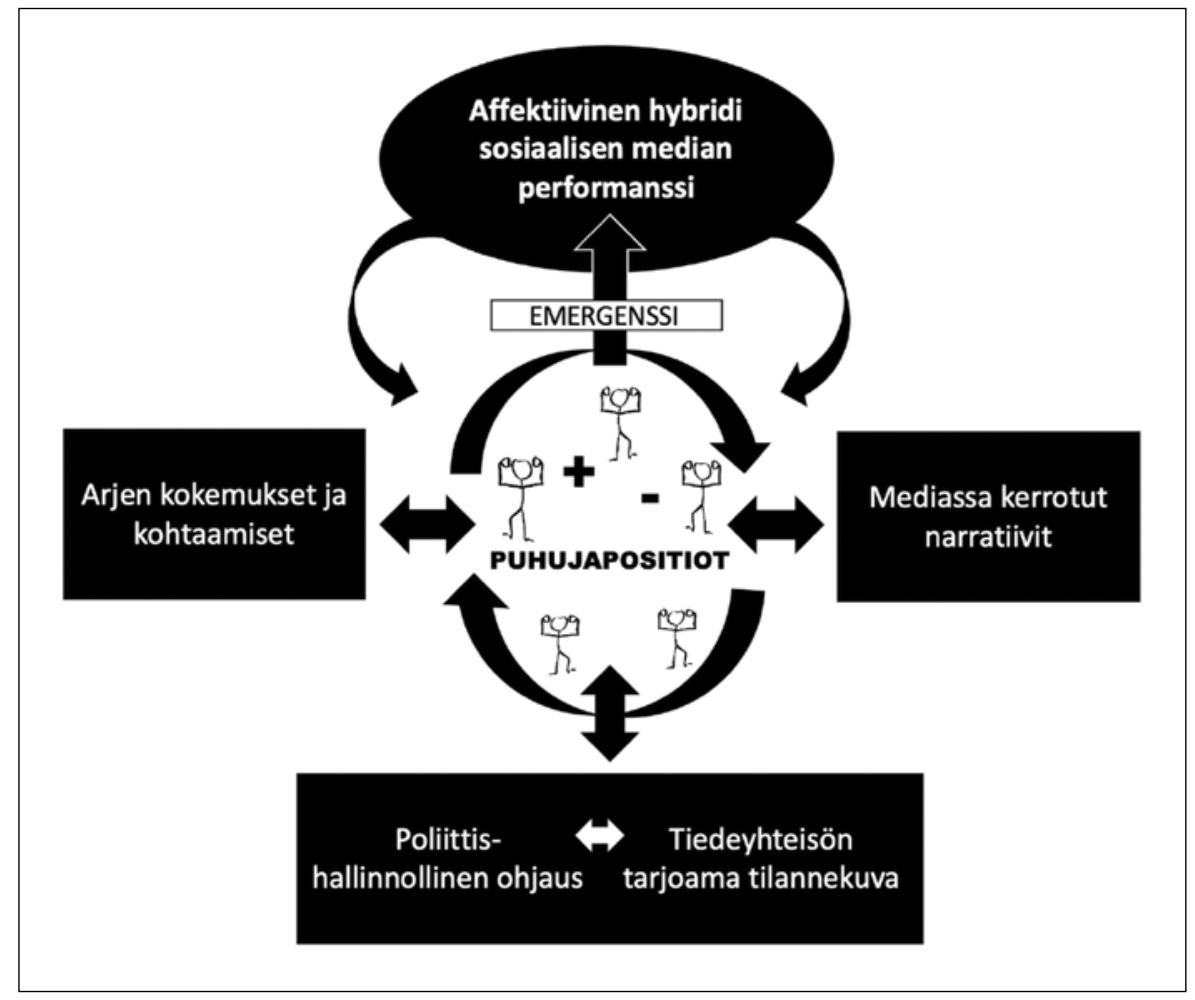

Parhaassa tapauksessa sosiaalisen median keskustelut resonoivat poliittis-hallinnollisen ohjauksen kanssa ja niissä työstetään rakentavassa hengessä muiden medioiden sisältöjä ja arjen kohtaamisia. Pahimmillaan performansseista muodostuu digitaalisia kansantuomioistuimia, joissa olennaista on hutkiminen ilman tutkimista. 
Seurauksena on lommoja sekä poliittis-hallinnolliseen että laajemmin asiantuntijuuden legitimiteettiin. Affektiivinen hybridi mediaperformanssi on samanaikaisesti sekä yksilöiden vuorovaikutussuhteissa ilmaantuva (emergence) kokonaisuus että yksilöiden vuorovaikutusta ohjaava rakenne (vrt. esim. Puustinen \& Jalonen 2020, 24-25). Toisin sanoen sanottu vaikuttaa kokonaisuuteen ja kokonaisuus sanomisen mielekkyyteen.

Koronapandemiaa voidaan luonnehtia Katzia ja Liebesiä (2007, 157-158) mukaillen hajottavaksi mediatapahtumaksi. Hajottavassa mediatapahtumassa on heidän mukaansa kysymys yhteiskunnan toimintaa vakavasti häiritsevän tai uhkaavan asian kollektiivisesta käsittelemisestä. Hajottavalle mediatapahtumalle on tyypillistä asian emotionaalinen käsitteleminen ja polarisoituvat mielipiteet. Koronapandemiassa on selkeästi näitä piirteitä. Tutkijapiireissä onkin perustellusti ennakoitu, että korona heikentää sosiaalista koheesiota (esim. Qureshi ym. 2020). Myös tässä artikkelissa esitetyn analyysin perusteella voidaan väittää, että koronavirus on ruokkinut negatiivisia tunteita, kuten pelkoa ja ahdistusta. Viestien teemat vaihtelevat ja ilmaisun sävyssä on eroja, mutta yhteistä monille niistä on se, että ihmiset ovat huolissaan siitä, miten heille käy, miten heidän läheisensä voivat, miten heidän yhteisönsä selviävät ja mitä tapahtuu Suomelle.

Artikkeli kontribuoi käytäntöön ja tutkimukseen erityisesti neljällä tavalla.

Ensinnäkin artikkelissa on osoitettu, että fragmentaarista sosiaalisen median aineistoa voidaan järjestää mielekkäästi puhujapositioiden avulla. Puhujapositio on määritelty artikkelissa puhetavaksi, jolla ja josta käsin ihminen viestii ja rakentaa samalla kuvaa itsestään. Puhujaposition hyödyntämisen haasteena on se, että positiot eivät aina esiinny puhtaasti toisistaan erillisinä. Päällekkäisyydestään huolimatta aineistoon kuuluvista sosiaalisen median viesteistä oli kuitenkin tulkittavissa hallitseva positio. Puhujapositiolähtöinen analyysi tarjoaa siten laajemman näkökulman kuin esimerkiksi tekstien tunnesävyjä (esim. sentiment analysis, ks. esim. Bae \& Lee 2012) tai puhujien motivaatioita tarkastelevat lähestymistavat (esim. users and gratification, ks. esim. Phua ym. 2017). Artikkelissa muodostetut puhujapositiot ovat luonteeltaan melko yleisiä ja siksi uskommekin, että niiden avulla on mahdollista jäsentää myös muunlaisia verkkokeskusteluja - erityisesti sellaisia keskusteluja, joissa argumentteja perustellaan sekä omakohtaisilla kokemuksilla että asiantuntijoiden sanomisilla.

Toiseksi puhujapositioiden analysointi on linjassa niiden tutkimusten kanssa, joissa suhtaudutaan kriittisesti sosiaalisen median kaikukammioiden (echo chamber, ks. Sunstein 2004) ja filtterikuplien (filter bubble, ks. Pariser 2011) yhteiskunnalliseen merkitykseen. Esimerkiksi Bruns (2019) pitää kaikukammiota ja kuplaa houkuttelevina metaforina, joille ei kuitenkaan löydy vahvaa ja yksiselitteistä empiiristä näyttöä. Hänen mukaansa kyse on enemminkin perusteettomasta moraalisesta paniikista, jossa sosiaalisen median alustoille on sovitettu syntipukin viittaa. Vaikka Bruns (emt.) ei kiistäkään esimerkiksi algoritmien vinouttavaa vaikutusta, hän näkee ongelman juurisyynä yhteiskunnan sosiaalisen kahtiajakautumisen. Sosiaalinen media voi vahvistaa kehitystä, mutta ei ole sen aiheuttaja. Parhaimmillaan erilaisten puhujapositioiden tunnistaminen ja niissä hyödynnettävien argumentaatiokeinojen analysointi voikin auttaa katsomaan polarisoitumisen ytimeen. 
Kolmanneksi puhujaposition käsitteeseen sisältyy implisiittisesti ajatus siitä, että ihmisen käyttäytymistä sosiaalisessa mediassa ei voida ymmärtää yksinomaan kiinnittämällä huomiota yksilön sosio-kulttuuriseen ympäristöön, sillä yhden ja saman ihmisen puhujapositio voi vaihdella tilanteen mukaan. Puhujapositioon sisältyy myös oletus puhujan intentiosta ja siksi puhujapositioiden voidaan katsoa heijastelevan puhujien omaksumia arvoja. Puhujapositioiden tarkastelu arvojen näkökulmasta mahdollistaa lähestymistavan kytkemisen arvostamisen konventioiden tutkimusperinteeseen (esteem, justification, worth, ks. esim. Brennan \& Pettit 2004; Boltanski \& Thévenot 2006; Stark 2009). Relevanteiksi kysymyksiksi tällöin nousevat ne kielelliset valinnat, joilla ihmisiä ja asioita osoitetaan arvokkaiksi. Tunnistamalla puhujapositioita sekä ymmärtämällä näiden taustalla vaikuttavia arvoja ja arvostamisen konventioita on mahdollista luoda merkityksellisiä, vaikuttavia ja aitoja kohtaamisia.

Neljänneksi analyysin perusteella voidaan sanoa, että koronapandemia houkuttelee vastajulkisuutta tavoittelevia performansseja (vrt. Fraser 1992, Warner 2002). Valtaosassa tunnistetuista puhujapositioista hyödynnetään vastajulkisuudelle ominaiseen tapaan valtajulkisuuden affektiivista ja kokemusperäistä haastamista (Dahlgren \& Alvares 2013, 50-51). Vaikka vastajulkisuuksia aiemman tutkimuksen mukaan muodostuu etenkin anonyymeillä keskustelufoorumeilla (ks. Vainikka \& Harju 2019, 102104), tämän tutkimuksen perusteella voidaan sanoa, että koronapandemia on lisännyt merkitysten kiertoa ja tehnyt sen käsittelystä siinä määrin mediariippumatonta, että valtajulkisuuden haastaminen tapahtuu myös omalla nimellä ja kasvoilla.

Lisäksi voidaan todeta, että koronapandemian kaltaiset globaalit uutistapahtumat ikään kuin kutsuvat luokseen tiettyjä arkkityyppisiä puhujapositioita. Affektiivinen hybridi sosiaalisen median performanssi syntyy yleisön, median ja päätöksentekijöiden yhteisvaikutuksesta. Agenda setting -teorian (McCombs \& Shaw 1972) mukaisesti tiedotusvälineet ohjaavat ja rajaavat julkista keskustelua. Usein mediat siilaavat yhteiskunnallisia teemoja siten, että kärkkäät äänenpainot ja tunteita herättävät näkökulmat saavat runsaasti näkyvyyttä (Karvonen 2008, 36). Siksi olisikin kiinnostavaa analysoida, kuinka huomio siirtyy pikavauhtia edestakaisin median, yleisön ja politiikan agendojen välillä (vrt. Tran 2013, 224). Ministerin tiedotustilaisuuden lausunnosta syntyy uutinen, jonka synnyttämää julkista keskustelua ministeri kommentoi jälleen median välityksellä. Puheenaiheisiin kiinnittyminen on näin osa laajaa ja jatkuvaa sosiaalista prosessia, jossa yksilöt samaistuvat median välityksellä suurempiin ryhmiin. Asettumalla jonkin julkisen agendan taakse yksilö luo itselleen yhteisön. Samalla yhteisön säilyttäminen edellyttää sitä, että yksilöt ajautuvat etsimään sellaista informaatiota, joka ei vaaranna heidän mahdollisuuksiaan kuulua ryhmään (Tran 2013, 225). Puhujapositioiden voidaankin ajatella syntyvän samankaltaisessa prosessissa, jossa korostuu yleisön aktiivinen rooli. Vastaanottotutkimuksen perustava ajatus on, että yleisön jäsenet lukevat kohtaamiaan mediatuotteita ikään kuin teksteinä tai diskursseina. Lukeminen ymmärretään aktiivisena toimintana. Tässä merkityksen tuottamisen prosessissa yleisö peilaa odotuksiaan, identiteettejään, kiinnostuksenkohteitaan ja esiymmärrystään mediailmiöihin. Koronapandemia mediatapahtumana on siis yhtäältä luonut tarpeen kiinnittyä ja sitoutua, mutta toisaalta se tarjoaa myös paikan 
itseymmärryksen kasvattamiselle ja jopa arvojen muutokselle (ks. Schrøder 2018, 105). Löytämissämme puhujapositioissa on kaikuja molemmista näkökulmista.

Puhujapositioiden analysointiin liittyy myös jatkotutkimustarpeita. Tässä tutkimuksessa hyödynnettiin laadullista sisällönanalyysiä, jonka toteuttaminen on aikaa vievää ja altis tutkijoiden subjektiivisille tulkinnoille (vrt. Krippendorff 2004). Lisäksi isojen aineistojen kohdalla laadullisen sisällönanalyysin toteuttaminen edellyttää aineiston merkittävää rajaamista. Tämän vuoksi yksi varteenotettava jatkotutkimusaihe onkin manuaalisen sisällönanalyysin ja tietokoneavusteisen analyysin yhdistäminen. Ohjatun ja ohjaamattoman koneoppimisen menetelmät kehittyvät nopeasti (esim. ShalevShwartz \& Ben-David 2014, Cheney-Lippold 2017). Esimerkiksi Toivasen ym. (2020, 8) mukaan koneoppimisen avulla voidaan edistää hybrideille mediatapahtumille tyypillistä isojen aineiston haltuunottoa ja kokonaiskuvan muodostamista sekä aineiston mielekästä rajaamista ajallisesti ja teemallisesti. Erityisen potentiaalisena voidaan pitää ohjaamattoman koneoppimisen menetelmiin luokiteltavaa aihemallinnusta (Blei ym. 2003). Aihemallinnuksen perusajatuksena on se, että menetelmän avulla voidaan ryhmitellä tekstiä ja "löytää sieltä piilossa olevia rakenteita tai aiheita" (Nelimarkka 2020, 9). Vaikka aihemallinnus onkin lupaava lähestymistapa suurten aineistojen jäsentämiseen, menetelmä ei ole 'hopealuoti', joka itsessään ratkaisee sisällönanalyysiin liittyvät haasteet. Muun muassa Nelimarkka $(2019,26)$ muistuttaa, että ohjaamattomien koneoppimismenetelmien hyödyntämisen ei pitäisi olla "teoriatonta". Muistutus on linjassa esimerkiksi Krippendorffin (2004) näkemyksen kanssa siitä, että sisällönanalyysillä tuotetuilla havainnoilla tulee olla yhteiskunnallista validiteettia. Luultavaa siksi onkin, että koronapandemian kaltaisessa hybridissä mediatapahtumassa otettujen puhujapositioiden analyysi on sitä osuvampi, mitä monimenetelmällisemmin sitä lähestytään (vrt. Toivanen ym. 2020, 16).

Tässä tutkimuksessa on esitetty läpileikkaus koronapandemiaa käsittelevistä lapsija perheaiheisista sosiaalisen median keskusteluista keväällä 2020. Tätä kirjoitettaessa ei ole tietoa pandemian loppumisesta eikä sen yhteiskunnallisista seurauksista. Vertauskuvallisesti ilmaistuna näyttää siltä, että koronan tartuttavuusluku on sosiaalisessa mediassa ollut reilusti yli yhden, mikä tarkoittaa sitä, että koronasta riittää puhetta jatkossakin.

\section{Kiitokset}

Kiitämme rakentavista huomioista artikkelikäsikirjoitusta kommentoineita Itsenäisyyden juhlavuoden lastensäätiön Petri Virtasta, Marika Tammeaidia ja Tiina Ristikaria sekä kahta anonyymiä vertaisarvioijaa. 


\section{Kirjallisuus}

Ainiala, Terhi; Räisä, Tiina \& Sjöblom, Paula (2020). Mediakeskustelun välittämä Tampereen yliopiston nimenvalintaprosessi osallistujien roolien, positioiden ja argumenttien valossa. Puhe ja kieli 40:1, 1-22. https://doi.org/10.23997/pk.95494

Alba, Davey (2020). Virus conspiracists elevate a new champion. New York Times, 9.5.2020.

Anderson, Cameron; John, Oliver, P. \& Keltner, Dacher (2012). The personal sense of power. Journal of Personality $80,313-344$.

Bae, Younggue \& Lee, Hongchul (2012). Sentiment analysis of twitter audiences: Measuring the positive or negative influence of popular twitterers. Journal of the American Society for Information Science Q Technology 63:12, 2521-2535. https://doi.org/10.1002/asi.22768

Blei, David; Bg, Andrew \& Jordan, Michael (2003). Latent Dirichlet allocation. Journal of Machine Learning Research 3:4-5, 993-1022.

Boltanski, Luc \& Thévenot, Laurent (2006). On Justification: Economies of Worth. Princeton, NJ: Princeton University Press.

Brennan, Geoffrey \& Pettit, Philip (2004). The Economy of Esteem. Oxford: Oxford University Press.

Bruns, Alex (2019). Are Filter Bubbles Real? Cambridge: Polity Press.

Chadwick, Andrew (2013). The Hybrid Media System: Politics and Power. Oxford: Oxford University Press.

Cheney-Lippold, John (2017). We Are Data: Algorithms and the Making of Our Digital Selves. New York: New York University Press. https://doi.org/10.2307/j.ctt1gko941

Dahlgren, Peter \& Alvares, Claudia (2013). Political participation in an age of mediatization. Javnost - The Public. Journal of the European Institute for Communication and Culture 20:2, 47-65. http://dx.doi.org/10.1080/13183222.2013.11009114

Erola, Jani; Niemelä, Mikko; Sirniö, Outi; Kailaheimo-Lönnqvist, Sanna; Heiskala, Laura; Jalovaara, Marika; Salonen, Laura \& Eskelinen, Niko (2020). Koronakriisin vaikutukset lasten ja nuorten oppimiseen, koulutukseen ja hyvinvointiin pitkällä aikavälillä. Invest-hankkeen policy brief 19.5.2020.

Saatavilla: https://www.utu.fi/fi/ajankohtaista/mediatiedote/koronakriisin-negatiivisia-vaikutuksia-lastenja-nuorten-oppimiseen (luettu 20.5.2020).

Fraser, Nancy (1992). Uusi katse julkisuuteen: Vallitsevan demokratian arvostelua. Suomentanut Veikko Pietilä. Media \& viestintä 32:3, 8-30. Alkuperäisartikkeli: Rethinking the public sphere: A contribution to critique of actually existing democracy. Teoksessa Calhoun,

Craig (toim.). Habermas and the Public Sphere. Cambridge: MIT Press. Saatavilla: https://journal.fi/mediaviestinta/article/view/62979 (luettu 22.112020).

Gao, Junling; Zheng, Pinpin; Jia, Yingnan; Chen, Hao; Mao, Yimeng; Chen, Suhong; Wang, Yi; Fu, Hua \& Dai, Junming (2020). Mental health problems and social media exposure during COVID-19 outbreak. Plos One, April 16, 2020. https://doi.org/10.2139/ssrn.3541120

Garfin, Dana R.; Silver, Roxane C. \& Holman, Alison E. (2020). The novel coronavirus (COVID-2019) outbreak: Amplification of public health consequences by media exposure. Health Psychology 39:5, 355-357. https://doi.org/10.1037/heaoooo875

Giglietto, Fabio; Iannelli, Laura; Valeriani, Augosto \& Rossi, Luca (2019). 'Fake news' is the invention of a liar: How false information circulates within the hybrid news system. Current Sociology 67:4, 625-642. https://doi.org/10.1177/0011392119837536

Goffman, Erving (1959). The Presentation of Self in Everyday Life. New York: Doubleday.

Golebiewski, Michael \& boyd, danah (2018). Data voids: Where missing data can easily be exploited. Data Q Society. Saatavilla: https://datasociety.net/wp-content/uploads/2018/05/Data_Society_Data_ Voids_Final_3.pdf (luettu 29.4.2020).

Habermas, Jürgen (1991). The public sphere. Teoksessa: Mukerji, Chandra \& Schudson, Michael, (toim.) Rethinking Popular Culture. Contemporary Perspectives in Cultural Studies. Los Angeles: University of California Press, 398-404.

Hollenbaugh, Erin E. \& Ferris, Amber L. (2014). Facebook self-disclosure: examining the role of traits, social cohesion, and motives. Computers in Human Behavior 30, 50-58. https://doi.org/10.1016/j.chb.2013.07.055

Jalonen, Harri; Ketonen-Oksi, Sanna; Pitkänen, Jatta \& Lehtimäki, Hanna (2020). Sitä saa, mitä tilaa? Kompleksisuuden kohtaaminen ja performatiivinen johtajuus sosiaalisessa mediassa. Teoksessa: Vartiainen, Pirkko \& Raisio, Harri (toim.). Johtaminen kompleksisessa maailmassa - Viisautta pirullisten ongelmien kohtaamiseen. Helsinki: Gaudeamus, 133-160. 
Jokinen, Arja (1999). Vakuuttelevan ja suostuttelevan retoriikan analysoiminen. Teoksessa: Jokinen, Arja; Juhila, Kirsi \& Suoninen, Eero (toim.). Diskurssianalyysi liikkeessä. Tampere: Vastapaino, 126-159.

Kahneman, Daniel (2011). Thinking, Fast and Slow. New York: Macmillan Publishers.

Kaila, Rajesh Prabhakar \& Prasad, Krishna A. V. (2020). Informational flow on Twitter - Corona Virus outbreak - topic modelling approach. International Journal of Advanced Research in Engineering and Technology 11:3, 128-134.

Karvonen, Erkki (2008). Poliitikot julkkiksina. Huomioita viihteellistyvästä poliitikkojulkisuudesta. Media Q viestintä 31:5, 30-55. https://doi.org/10.23983/mv.63002

Katz, Elihu \& Liebes, Tamara (2007). 'No more peace!' How disaster, terror and war have upstaged media events. International Journal of Communication 1, 157-166.

Kennedy, George A. (1994). A New History of Classical Rhetoric. New Jersey, NJ: Princeton University Press.

Kokkola, Jussi; Kankaanpää, Vesa \& Raunio, Samuel (2020). "Radioaktiivinen vegaani" - puhujapositioiden arvo dialogisessa kohtaamisessa. Teoksessa: Jalonen, Harri; Helander, Nina \& Mäkelä Leena (toim.). Arvostustalous. Kuinka arvostus rakennetaan ja rakentuu digiyhteiskunnassa. Tampere: Vastapaino, 259292.

Krauss, Steven (2005). Research paradigms and meaning making: A primer. The Qualitative Report, 10:4, 758-770.

Krippendorff, Klaus (2004). Content Analysis. An Introduction to Its Methodology. Thousand Oaks: Sage Publications.

Markham, Annette \& Buchanan, Elizabeth (2012). Ethical Decision-Making and Internet Research: Recommendations from the AoIR Ethics Working Committee (Version 2.0). Saatavilla: https://aoir.org/reports/ethics2.pdf (luettu 1.5.2020).

McCombs, Maxwell \& Shaw, Eugene F. (1972). The agenda-setting function of the media. Public Opinion Quarterly 36, 176-187. https://doi.org/10.1086/267990

Mohawk Analytics (2020). Palvelu saatavilla: https://www.mohawkanalytics.com (luettu 18.5.2020).

Nelimarkka, Matti (2019). Aihemallinnus sekä muut ohjaamattomat koneoppimismenetelmät yhteiskuntatieteellisessä tutkimuksessa: kriittisiä havaintoja. Politiikka 61:1, 6-33.

Papacharissi, Zizi (2015). Affective Publics: Sentiment, Technology, and Politics. New York: Oxford University Press.

Pariser, Eli (2011). The Filter Bubble. What the Internet Is Hiding from You. London: Penguin Group.

Phua, Joe; Venus Jin, Seunga \& Kim, Jihoon (2017). Uses and gratifications of social networking sites for bridging and bonding social capital: A comparison of Facebook, Twitter, Instagram, and Snapchat. Computers in Human Behavior, 72, 115-122. https://doi.org/10.1016/j.chb.2017.02.041

Puro, Jukka-Pekka (2005). Retoriikan historia. Helsinki: WSOY.

Puustinen, Alisa \& Jalonen, Harri (2020). Kompleksisuusajattelu - ymmärtämistä edistävä uusi lähestymistapa vai vanhaa viiniä uudessa pullossa? Teoksessa Vartiainen, Pirkko \& Raisio, Harri (toim.) Johtaminen kompleksisessa maailmassa. Viisautta pirullisten ongelmien kohtaamiseen. Tampere: Vastapaino, 15-36.

Pälli, Pekka (2003). Ihmisryhmä diskurssissa ja diskurssina. Acta Universitatis Tamperensis 910. Tampere: Tampere University Press.

Qureshi, Israr; Bhatt, Babita; Gupta, Samrat \& Anand Tiwari, Amit (2020). Causes, symptoms and consequences of social media induced polarization. Kirjoittajakutsu Information Systems Journal -lehden erikoisnumeroon. Saatavilla: https://onlinelibrary.wiley.com/pb-assets/assets/13652575/ISJ_SMIP_ CFP\%20(002).pdf (luettu 18.5.2020).

Riessman, Cathy K. (2008). Narrative methods for the human sciences. Thousand Oaks: Sage Publications.

Ruoho, liris \& Kuusipalo, Jaana (2018). Läsnäolon valtaa: Politiikan ja median eliittiverkostot Twitterissä. Teoksessa: Isotalus, Pekka; Jussila, Jari \& Matikainen, Janne (toim.). Twitter viestintänä - IImiöt ja verkostot. Tampere: Vastapaino, 51-65.

Schrøder, Kim Christian (2018). Audience Reception. Teoksessa: Napoli, Philip M. (toim.). Mediated Communication. Berlin: De Gruyter, 105-128. https://doi.org/10.1515/9783110481129-008

Shalev-Shwartz, Shai \& Ben-David, Shai (2014). Understanding Machine Learning: from Theory to Algorithms. New York, NY: Cambridge University Press. https://doi.org/10.1017/cbo9781107298019

Sonnevend, Julia (2016). Stories without Borders. The Berlin Wall and the Making of a Global Iconic Event. New York, NY: Oxford University Press. https://doi.org/10.1093/acprof:0so/9780190604301.001.0001

Stark, David (2009). The Sense of Dissonance: Accounts of Worth in Economic Life. Princeton, NJ: Princeton University Press. 
Sumiala, Johanna; Tikka, Minttu; Huhtamäki, Jukka \& Valaskivi, Katja (2016). \#JeSuisCharlie. Towards a multi-method study of hybrid media event. Media and Communication 4:4, 97-108. https://doi.org/10.17645/mac.v4i4.593

Sunstein, Cass (2004). Democracy and filtering. Communications of the ACM 47:12, 57-59.

Sunstein, Cass (2017). \#Republic Divided Democracy in the Age of Social Media. New Jersey: Princeton University Press.

Toffler, Alvin (1980). The Third Wave. New York: William Morrow.

Toivanen, Pihla, Huhtamäki, Jukka; Valaskivi, Katja \& Tikka, Minttu (2020). Aihemallinnus hybridin mediatapahtuman ja merkitysten kierron tutkimuksessa. Media Q viestintä 43:1, 1-20. https://doi.org/10.23983/mv.91078

Toivonen, Timo (1999). Empiirinen sosiaalitutkimus. Filosofia ja metodologia. Juva: WSOY.

Tran, Hai (2013). Online agenda setting: A new frontier for theory development. Teoksessa: Johnson, Thomas (toim.). Agenda Setting in a 2.0 World: A Tribute to Maxwell McCombs. New York: Routledge.

Tuomi, Jouni \& Sarajärvi, Anneli (2004). Laadullinen tutkimus ja sisällönanalyysi. Jyväskylä: Gummerus Kirjapaino Oy.

Vainikka, Eliisa \& Harju, Auli (2019). Anonyymien keskustelupalstojen julkisuus. Marginaaliin jääneiden vertaistukea ja yhteiskuntakritiikkiä. Media Q viestintä 42:2, 99-121. https://doi.org/10.23983/mv.83374

Vaccari, Christian; Chadwck, Andrew \& O'Loughlin, Ben (2015). Dual screening the political: Media events, social media, and citizen engagement. Journal of Communication 65:6, 1041-1061. https://doi.org/10.1111/jcom.12187

Valaskivi, Katja \& Sumiala, Johanna (2014). Circulating social imaginaries: Theoretical and methodological reflections. European Journal of Cultural Studies 17:3, 229-243. https://doi.org/10.1177/1367549413508741

Villi, Mikko (2011). Sosiaalinen kuratointi verkossa Mediasisältöjen sosiaalinen kulutus ja osallistava yleisöys. Media Q viestintä 34:4, 48-65. https://doi.org/10.23983/mv.62899

Virsu, Ville (2007). Sosiaalisten ongelmien retoriikkaa: tapaus doping. Virittäjä 111, 346-366.

Warner, Michael (2002). Publics and counterpublics. Public Culture 14:1, 49-90.

Williams, Raymond (1961). The Long Revolution. London: Chatto and Windus.

Woolley, Samuel C. \& Howard, Philip N. (2018). Computational Propaganda. Political Parties, Politicians, and Political Manipulation on Social Media. Oxford: Oxford University Press.

Vosoughi, Soroush; Roy, Deb \& Aral, Sinan (2018). The spread of true and false news online. Science, 359:6380, 1146-1151. https://doi.org/10.1126/science.aap9559 